\title{
Brain Pericytes ABCA1 Expression Mediates Cholesterol Efflux but not Cellular Amyloid- $\beta$ Peptide Accumulation
}

\author{
Julien Saint-Pol ${ }^{\mathrm{a}, \mathrm{b}, \mathrm{c}}$, Elodie Vandenhaute ${ }^{\mathrm{a}, \mathrm{b}, \mathrm{c}}$, Marie-Christine Boucau ${ }^{\mathrm{a}, \mathrm{b}, \mathrm{c}}$, Pietra Candela ${ }^{\mathrm{a}, \mathrm{b}, \mathrm{c}}$, \\ Lucie Dehouck $^{\mathrm{a}, \mathrm{b}, \mathrm{c}}$, Roméo Cecchelli ${ }^{\mathrm{a}, \mathrm{b}, \mathrm{c}}$, Marie-Pierre Dehouck ${ }^{\mathrm{a}, \mathrm{b}, \mathrm{c}}$, Laurence Fenart ${ }^{\mathrm{a}, \mathrm{b}, \mathrm{c}}$ \\ and Fabien Gosselet ${ }^{\mathrm{a}, \mathrm{b}, \mathrm{c}, *}$ \\ ${ }^{\mathrm{a}}$ Univ Lille Nord de France, Lille, France \\ ${ }^{\mathrm{b}}$ UArtois, LBHE, Lens, France \\ ${ }^{\mathrm{c}}$ IMPRT-IFR114, Lille, France
}

Handling Associate Editor: Othman Ghribi

Accepted 15 February 2012

\begin{abstract}
In brain, excess cholesterol is metabolized into 24S-hydroxycholesterol (24S-OH-chol) and eliminated into the circulation across the blood-brain barrier. 24S-OH-chol is a natural agonist of the nuclear liver X receptors (LXRs) involved in peripheral cholesterol homeostasis. The effects of this oxysterol on the pericytes embedded in the basal lamina of this barrier (close to the brain compartment) have not been previously studied. We used primary cultures of brain pericytes to demonstrate that the latter express LXR nuclear receptors and their target gene ATP-binding cassette, sub-family A, member 1 (ABCA1), known to be one of the major transporters involved in peripheral lipid homeostasis. Treatment with $24 \mathrm{~S}-\mathrm{OH}$-chol caused an increase in ABCA1 expression that correlated with a reverse cholesterol transfer to apolipoprotein E, apolipoprotein A-I, and high density lipoprotein particles. Inhibition of ABCA1 decreased this efflux. As pericytes are able to internalize the amyloid- $\beta$ peptides which accumulate in brain of Alzheimer's disease patients, we then investigated the effects of 24S-OH-chol on this process. We found that the cellular accumulation process was not modified by $24 \mathrm{~S}-\mathrm{OH}$-chol treatment. Overall, our results highlight the importance of the LXR/ABCA1 system in brain pericytes and suggest a new role for these cells in brain cholesterol homeostasis.
\end{abstract}

Keywords: 24S-hydroxycholesterol, ABCA1, Alzheimer's disease, amyloid- $\beta$ peptides, liver X receptors, pericytes

Supplementary data available online: http://dx.doi.org/10.3233/JAD-2012-112090

\section{INTRODUCTION}

In brain, cholesterol homeostasis is a complex and poorly understood process. It is now well accepted

*Correspondence to: Dr. Fabien Gosselet, Université d'Artois, Laboratoire de Physiopathologie de la Barrière Hématoencéphalique, EA 2465 - IMPRT 114, Faculté Jean Perrin, Rue Jean Souvraz, S.P. 18, F-62300 Lens, France. Tel.: +33 321 791780; Fax: +33 321 791736; E-mail: fabien.gosselet@univ-artois.fr. that cholesterol is synthesized de novo by glial cells, secreted to lipoproteins (with a density similar to high density lipoproteins, HDL) via a reverse cholesterol process, and then shuttled to neurons, which use this sterol for synaptogenesis and membrane repair [1]. In neurons, excess cholesterol is oxidized in 24S-hydroxycholesterol (24S-OH-chol, initially named as "cerebrosterol") by the brainspecific enzyme CYP46A1 [2]. Cerebrosterol can diffuse across cell membranes [3] and can thus be 
eliminated into the peripheral circulation across the blood-brain barrier (BBB), which isolates the brain from the rest of the body [4, 5]. However, 24S-OHchol is also a natural ligand for the nuclear liver $\mathrm{X}$ receptors $(\mathrm{LXR} \alpha$ and $\mathrm{LXR} \beta)$ [2]. In brain, these receptors sense the intracellular cholesterol concentration and control the transcription of the protagonists in reverse cholesterol transfer, such as the ATPbinding cassette sub-family A member 1 (ABCA1) and sub-family $\mathrm{G}$ member 1 (ABCG1) transporters, both of which are involved in cholesterol transfer to apolipoprotein (apo)E- and apoA-I-lipid-poor particles and HDL [6]. Indeed, in vitro experiments have shown that 24S-OH-chol or synthetic agonists of LXRs (such as the lipid-lowering drugs T0901317 and GW683965A) promote cholesterol efflux from astrocytes [7-9], oligodendrocytes [10], neurons [7, $11,12]$, and choroid plexus epithelial cells [13] to apoA-I, apoE, and HDL particles. Elucidation of the contribution of the LXR pathway and $24 \mathrm{~S}-\mathrm{OH}-\mathrm{chol}$ to brain cholesterol homeostasis has now become essential, since several studies have highlighted a close relationship between these nuclear receptors, cholesterol metabolism, and the accumulation and deposition of amyloid- $\beta(A \beta)$ peptides, particularly the $A \beta_{40}$ and $A \beta_{42}$ forms. Amyloid build-up in the brain of Alzheimer's disease (AD) patients leads slowly to neurodegeneration. Thus, in several transgenic mouse models of $\mathrm{AD}$, treatment with synthetic LXR agonists modulates brain ABCA1 expression, improves cognitive function, and decreases the amyloid burden [14-19]. Moreover, AD neuropathology is exacerbated in transgenic mice that lack both LXRs [20]. However, the cellular and molecular mechanisms underlying these observations are still not well understood.

Given that the BBB is thought to be involved in the complex process of brain cholesterol homeostasis [21-23] and in $A \beta$ peptide exchanges between the blood and the brain (reviewed in [24]), it is essential to investigate the role of LXRs at the BBB level. The BBB is composed of brain capillary endothelial cells (BCECs), which are surrounded by pericytes. The latter are important for the development, maturation, and maintenance of the properties of BBB $[25,26]$. In both in vitro and in vivo experiments, we and others have already demonstrated that BCECs and pericytes express LXR and their target genes (such as ABCA1) [21-23, 27-30]. Given that as much as 6 to $7 \mathrm{mg}$ of $24 \mathrm{~S}-\mathrm{OH}$-chol crosses the BBB per $24 \mathrm{~h}$ [5], it is not surprising that this oxysterol increases the expression of ABCA1 and raises cholesterol release from BCECs to apoA-I and HDL particles [23, 28, 29]. Although
$24 \mathrm{~S}-\mathrm{OH}-\mathrm{chol}$ and $\mathrm{A} \beta$ peptides first encounter pericytes before being eliminated across the BBB, no studies have focused on the oxysterol's potential impact on pericyte cholesterol efflux and $A \beta$ peptide internalization.

With these considerations in mind, the objective of the present study was to characterize the molecular effects of activation of the LXR signaling pathway by its natural agonist $24 \mathrm{~S}-\mathrm{OH}$-chol in brain pericytes and to determine the consequences of this activation on cellular reverse cholesterol transfer and cellular $A \beta$ peptide accumulation.

\section{MATERIALS AND METHODS}

\section{Chemicals}

24S-OH-chol and T0901317 were purchased respectively from Enzo Life Science (Villeurbane, France) and Sigma (St Louis, MO, USA). They were dissolved in dimethyl sulfoxide (DMSO) (Sigma) at a concentration of $24.8 \mathrm{mM}$ and $10.4 \mathrm{mM}$, respectively. ApoA-I and HDL were purchased from VWR (Fontenay-sous-Bois, France). ApoE2 and E4 were purchased from Clini Sciences (Montrouge, France) and were resuspended in sterile water at a concentration of $1 \mathrm{mg} / \mathrm{mL}$. Glyburide and probucol were also purchased from Sigma and were dissolved in DMSO at a concentration of $50 \mathrm{mM}$ and $5 \mathrm{mM}$, respectively. Bovine serum albumin (BSA) was also purchased from Sigma. $\left[{ }^{3} \mathrm{H}\right]$ cholesterol $(43 \mathrm{Ci} / \mathrm{mmol})$ and $\left[{ }^{3} \mathrm{H}\right]$ inulin $(1.25 \mathrm{Ci} / \mathrm{mmol})$ were purchased from PerkinElmer Life and Analytical Sciences (Waltham, MA, USA). 24S$\left[{ }^{3} \mathrm{H}\right]$ hydroxycholesterol $(30 \mathrm{Ci} / \mathrm{mmol})$ was purchased from Biotrend $\mathrm{GmbH}$ (Köln, Germany). Ultrapure forms of $A \beta_{1-40}$ and $A \beta_{1-42}$ peptides were purchased from Invitrogen (Cergy Pontoise, France). Lyophilized peptides were reconstituted following the manufacturer's instructions to avoid peptide aggregation, as previously described [31]. Briefly, peptides were dissolved in $100 \%$ 1,1,1,3,3,3-hexafluoro-2propanol (from Sigma) and dried. They were then resuspended in $100 \%$ DMSO and stored at $-80^{\circ} \mathrm{C}$ in phosphate buffered saline (PBS)/5\% BSA/0.03\% Tween.

\section{Isolation of brain microvascular pericytes and cell culture}

All animal experimentation was done according to the French Veterinary Council's guide. Brain pericytes were isolated according to the method described by 
Vandenhaute and colleagues [32]. Briefly, bovine brain capillaries were isolated as previously described [33] and were subsequently collected on a $60-\mu \mathrm{m}$ nylon sieve, washed in warm PBS, and resuspended in a 60mm Petri dish containing Dulbecco's modified Eagle's medium (DMEM) supplemented with $20 \%$ fetal calf serum (FCS, Hyclone Laboratories, Logan, UT, USA), $2 \mathrm{mM}$ L-glutamine, $50 \mu \mathrm{g} / \mathrm{mL}$ gentamicin, and basic fibroblast growth factor (bFGF). This microvascular suspension mainly comprised capillaries, as assessed by phase-contrast microscopy. It was briefly mechanically dissociated and immediately dispatched into 12 Matrigel-coated dishes containing DMEM supplemented with $20 \%$ FCS, $2 \mathrm{mM}$ L-glutamine, $50 \mu \mathrm{g} / \mathrm{mL}$ gentamicin, and $1 \mathrm{ng} / \mathrm{mL}$ bFGF. On the following day, $60 \mathrm{~mm}$ Petri dishes were carefully screened for large vessels. Each large vessel was scraped and discarded. Pericytes and endothelial cells migrated from the vessel walls. Pericytes rapidly overgrew the few endothelial cells and invaded the whole surface of the dish. Confluent cultures (consisting almost exclusively of pericytes) were dissociated with $0.05 \%$ trypsin/0.02\% EDTA saline buffer (Biochrom AG, Berlin, Germany), and cells were frozen in liquid nitrogen (one Petri dish per vial). For experiments, each pericyte vial was rapidly thawed and seeded in $60 \mathrm{~mm}$ Petri dishes containing DMEM supplemented with $20 \%$ FCS, $2 \mathrm{mM}$ L-glutamine, $50 \mu \mathrm{g} / \mathrm{mL}$ gentamicin, and $1 \mathrm{ng} / \mathrm{mL}$ bFGF. After defrosting, there were no endothelial cells left in the cultures. Pericytes were subcultured at a $1: 3$ split ratio and were used for $\leq 4$ passages.

\section{Immunofluorescence studies on brain pericyte cultures}

Brain pericytes were double-immunostained for $\alpha$-Smooth Muscle Actin ( $\alpha$-SMA) and NeuronGlial 2 (NG2), two markers used to identify pericytes in culture. First, cells were washed with Ringer-HEPES (RH) buffer $(150 \mathrm{mM} \mathrm{NaCl}, 5.2 \mathrm{mM}$ $\mathrm{KCl}, 2.2 \mathrm{mM} \mathrm{CaCl} 2,0.2 \mathrm{mM} \mathrm{MgCl} 2-6 \mathrm{H}_{2} \mathrm{O}, 6 \mathrm{mM}$ $\mathrm{NaHCO}_{3}, 5 \mathrm{mM}$ HEPES, $2.8 \mathrm{mM}$ glucose, $\mathrm{pH}$ 7.4), fixed in methanol/acetone (v/v) for $1 \mathrm{~min}$ and washed three times with PBS-CMF $\left(8.0\right.$ g.L $\mathrm{L}^{-1} \mathrm{NaCl}$, 0.2 g.L $\mathrm{L}^{-1} \mathrm{KCl}, 0.2 \mathrm{~g} . \mathrm{L}^{-1} \mathrm{KH}_{2} \mathrm{PO}_{4}$ and $2.87 \mathrm{~g} . \mathrm{L}^{-1}$ $\mathrm{Na}_{2} \mathrm{HPO}_{4}\left(12 \mathrm{H}_{2} \mathrm{O}\right)$, pH 7.4). Following a 30-min incubation step in PBS-CMF supplemented with $10 \%$ (v/v) normal goat serum (NGS), cells were incubated with the first primary antibody for $1 \mathrm{~h}$ at room temperature (mouse anti- $\alpha$-SMA, clone 1A4, Dako, Glostrup, Denmark; dilution 1/200 in PBS-CMF supplemented with
$2 \%$ NGS). After this first incubation step, preparations were washed three times in PBS-CMF supplemented with $2 \%$ NGS, and then incubated with the second primary antibody (rabbit anti-NG2, Millipore, Temecula, California, USA; dilution 1/200 in PBS-CMF supplemented with $2 \%$ NGS) for $1 \mathrm{~h}$ at room temperature. After 3 washes in PBS-CMF supplemented with 2\% NGS, preparations were consecutively incubated in the dark with the secondary antibodies for $30 \mathrm{~min}$ at room temperature (Alexa Fluor ${ }^{\circledR} 488$-conjugated goat anti-rabbit IgG and Alexa Fluor ${ }^{\circledR}$ 568-conjugated antimouse IgG, Molecular Probes, Eugene, Oregon, USA). Then, cells were mounted using Mowiol (Sigma) containing DABCO (Sigma) as an anti-quenching agent. Cells were observed using a Leica DMRD fluorescence microscope (Leica Microsystems, Wetzlar, Germany). Images were collected using a Cool SNAP RS Photometrics camera (Leica Microsystems) and were processed using Adobe Photoshop software version 5.5 (Adobe Systems, San Jose, CA, USA).

\section{$R N A$ extraction and reverse transcription- polymerase chain reaction ( $R T-P C R)$}

$24 \mathrm{~h}$ after refreshment of the medium, pericytes were treated with various concentrations of $24 \mathrm{~S}-\mathrm{OH}-$ chol or T0901317 $(0.1,1$, and $10 \mu \mathrm{M})$. After $24 \mathrm{~h}$ of treatment, cells were rinsed twice in sterile cold PBS buffer and lysed using RLT lysis buffer (Qiagen, Valencia, CA, USA). Experiments were also performed after 6 and $12 \mathrm{~h}$ of treatment (results not shown). Three wells of pericytes were used for each condition. Extraction of total RNA was performed using the RNeasy total RNA extraction kit (Qiagen) according to the manufacturer's protocol. RNA bovine liver extract was obtained from Biochain (Hayward, CA, USA). Single-strand DNA was synthesized from $1 \mu \mathrm{g}$ of total RNA by reverse transcription using Moloney murine leukemia virus reverse transcriptase (Invitrogen). DNA was amplified with specific conditions and primers (all custom-synthesized by Invitrogen), as described in Table 1 . The primers' ability to recognize and amplify Abcgl DNA efficiently had already been assessed in bovine endothelial cells and bovine capillary extracts [27]. The RT-PCR products were resolved with $1.5 \%$ agarose gel electrophoresis, revealed with dilution 1:12500-diluted GelRed ${ }^{\circledR}$ stain (Interchim, Montluçon, France) and visualized using Gel Doc ${ }^{\mathrm{TM}}$ XR (Bio-Rad, Marnes-la-Coquette, France). Quantification was performed with Quantity One software (Bio-Rad). All corresponding fragments were identified by sequencing (Genoscreen, Lille, France). 
Table 1

DNA primers and conditions used to amplify mRNA in brain pericytes, liver extracts and brain capillary endothelial cells

\begin{tabular}{|c|c|c|c|c|c|c|c|}
\hline mRNA & Species & Accession number & $\mathrm{F} / \mathrm{R}$ & Sequence & Size (bp) & $\mathrm{Ta}\left(\mathrm{C}^{\circ}\right)$ & Number of cycles \\
\hline \multirow[t]{2}{*}{ ABCA1 } & Bos taurus & NM_001024693 & $\mathrm{F}$ & $5^{\prime}$-gTgTCTCgCCTgTTCTCAg-3' & 540 & 55 & 35 \\
\hline & & & $\mathrm{R}$ & $5^{\prime}$-gAAACATCACCTCCTgCCg-3' & & & \\
\hline \multirow[t]{2}{*}{ ABCG1 } & Homo sapiens & ВC029158 & $\mathrm{F}$ & $5^{\prime}$-gAggAAgAAAggATACAAGACC-3' & 330 & 55 & 35 \\
\hline & & & $\mathrm{R}$ & 5'-gTCAgTATCTCCTTgACCATTT-3' & & & \\
\hline \multirow[t]{2}{*}{ LRP1 } & Mus musculus & NM_008512 & $\mathrm{F}$ & $5^{\prime}$-gCATCCTgATCgAgCACCTg- $3^{\prime}$ & 531 & 60 & 25 \\
\hline & & & $\mathrm{R}$ & $5^{\prime}$-gCCAATgAggTAgCTggTgg-3' & & & \\
\hline \multirow[t]{2}{*}{ P-gp } & Bos taurus & AB006985 & $\mathrm{F}$ & $5^{\prime}$-gCAAgAggAgCAgCTTATgAAg-3' & 185 & 50 & 30 \\
\hline & & & $\mathrm{R}$ & $5^{\prime}$-ACTCCCTACCTTCAAgTTgAgg-3' & & & \\
\hline \multirow[t]{2}{*}{$\mathrm{LXR} \alpha$} & Bos taurus & ВТ021004 & $\mathrm{F}$ & $5^{\prime}$-ATCCgTCTgAAgAAAATgAAg-3' & 259 & 55 & 32 \\
\hline & & & $\mathrm{R}$ & $5^{\prime}$-AgCTCAgTgAAgTgAgCAAAg-3' & & & \\
\hline \multirow[t]{2}{*}{ LXR $\beta$} & Bos taurus & ВТ021903 & $\mathrm{F}$ & 5'-AgTgCAATAAACgCTCCТTCTC-3' & 268 & 55 & 35 \\
\hline & & & $\mathrm{R}$ & 5'-CACTCAgTCTCgTggTTgTAgC-3' & & & \\
\hline \multirow[t]{2}{*}{ RAGE } & Bos taurus & NM 173982 & $\mathrm{~F}$ & $5^{\prime}-\mathrm{CTggAATggAAACTgAACaC}-3^{\prime}$ & 196 & 60 & 30 \\
\hline & & & $\mathrm{R}$ & 5'-CTCggTAgTTAgACTTggTCTC-3' & & & \\
\hline \multirow[t]{2}{*}{$\beta$-Actin } & Rattus norvegicus & NM_031144 & $\mathrm{F}$ & $5^{\prime}$-gAAgTACCCCATTgAACACg-3' & 177 & 55 & 25 \\
\hline & & & $\mathrm{R}$ & $5^{\prime}$-ggTCTCAAACATgATCTggg-3' & & & \\
\hline
\end{tabular}

From left to right: cDNA targeted for amplification, species used for design primers, accession numbers of cDNA from NCBI database, Forward (F), Reverse (R) primer designation, $5^{\prime}$ to $3^{\prime}$ primer sequence, size in bp of amplification, PCR annealing temperature in ${ }^{\circ} \mathrm{C}$ and number of cycles to amplify cDNA.

\section{Immunoblots}

After treatment, cells were washed twice with warm PBS and scraped in RIPA buffer containing $50 \mathrm{mM}$ Tris- $\mathrm{HCl}$ (pH 7.4), $150 \mathrm{mM} \mathrm{NaCl}, 0.25 \%$ deoxycholic acid, 1\% NP-40, and 1 mM EDTA supplemented with phosphatase and protease inhibitor cocktails (Sigma). The lysate protein concentration was measured by the Bradford method, using Bio-Rad Protein Assay reagent (Bio-Rad). For plasma membrane fractions, pericytes were cultured in $100 \mathrm{~mm}$ gelatine-coated dishes. At $60-80 \%$ of confluence, cells were treated with DMSO (control) or $10 \mu \mathrm{M}$ T0901317 or 24S-OH-chol (agonists). Ten dishes were used for each condition. After $24 \mathrm{~h}$ of treatment, cells were rinsed twice with $20 \mathrm{mM}$ tricine $/ 250 \mathrm{mM}$ sucrose/1 mM EDTA buffer and scraped. Lysates were then centrifuged at $2500 \mathrm{rpm}$ for $5 \mathrm{~min}$ at $4^{\circ} \mathrm{C}$. Pellets were resuspended in buffer and dissociated using a mechanical pestle. The homogenized sample was centrifuged at $4000 \mathrm{rpm}$ for $10 \mathrm{~min}$ at $4{ }^{\circ} \mathrm{C}$ and the supernatants were transferred onto a $30 \%$ Percoll solution (GE Healthcare, Saclay, France) (ratio 1/10.5) before ultracentrifugation at $30,000 \mathrm{rpm}$ for $30 \mathrm{~min}$ at $4{ }^{\circ} \mathrm{C}$. Membrane proteins were collected and protein concentrations were measured as described above.

Next, $30 \mu \mathrm{g}$ of total proteins or $5.4 \mu \mathrm{g}$ of membrane proteins were electrophoresed on a $7.5 \%$ sodium dodecyl sulphate (SDS)-polyacrylamide gel (Bio-Rad) and subsequently electrotransferred to nitrocellulose membranes (GE Healthcare). Membranes were treated with blocking buffer $(25 \mathrm{mM}$ Tris- $\mathrm{HCl}$
(pH 8.0), $125 \mathrm{mM} \mathrm{NaCl}, 0.1 \%$ Tween 20 , and $5 \%$ skimmed milk) for $90 \mathrm{~min}$ at $37^{\circ} \mathrm{C}$ and then incubated with primary antibody (anti-ABCA1 antibody $(2 \mu \mathrm{g} / \mathrm{mL})$, anti-SCARB1 $(0.4 \mu \mathrm{g} / \mathrm{mL})$, anti-ABCG1 antibody $(5 \mu \mathrm{g} / \mathrm{mL})$, anti-Pgp $(5 \mu \mathrm{g} / \mathrm{mL})$, anti-RAGE $(1 \mu \mathrm{g} / \mathrm{mL})$, anti-LXR $\alpha / \beta$ antibody $(1 \mu \mathrm{g} / \mathrm{mL} ;$ Abcam, Cambridge, UK), anti-LRP1 $(0.5 \mu \mathrm{g} / \mathrm{mL}$; Santa Cruz Biotechnology, Santa Cruz, CA, USA), or anti- $\beta$-tubulin antibody $(1 \mu \mathrm{g} / \mathrm{mL}$; Cell Signaling Technology, Danvers, MA, USA)) overnight at $4{ }^{\circ} \mathrm{C}$. The membranes were washed three times with blocking buffer and incubated with adequate horseradish peroxidase-conjugated secondary antibody. Immunoreactivity was visualized with an enhanced chemiluminescence kit (GE Healthcare) and developed with X-Omat AR film (Kodak, NY, USA). The relative densities of the bands were measured using TotalLab TL 100 1D Gel Analysis software (Nonlinear Dynamics, Newcastle, UK).

\section{Cellular cholesterol efflux studies}

Before the cell labeling, $\left[{ }^{3} \mathrm{H}\right]$ cholesterol or $24 \mathrm{~S}$ $\left[{ }^{3} \mathrm{H}\right]$ hydroxycholesterol was incorporated into the serum for $6 \mathrm{~h}$ at $37^{\circ} \mathrm{C}$, in order to obtain a FCS radioactive medium $(0.5 \mu \mathrm{Ci} / \mathrm{mL}$ and $0.1 \mu \mathrm{Ci} / \mathrm{mL}$, respectively). Next, pericytes were incubated with $\left[{ }^{3} \mathrm{H}\right]$ cholesterol medium for $36 \mathrm{~h}$ or with $24 \mathrm{~S}$ $\left[{ }^{3} \mathrm{H}\right]$ hydroxycholesterol medium for $14 \mathrm{~h}$. At the end of this step, cells were labeled with radioactive cholesterol. The "labeling" medium was then replaced (after 
two washes with pre-warmed PBS and one wash with pre-warmed DMEM/0.1\% BSA) by DMEM/0.1\% BSA for $24 \mathrm{~h}$ to equilibrate $\left[{ }^{3} \mathrm{H}\right]$ cholesterol or for $1 \mathrm{~h}$ to equilibrate $24 \mathrm{~S}-\left[{ }^{3} \mathrm{H}\right]$ hydroxycholesterol across the cellular pools. Where indicated, $10 \mu \mathrm{M} 24 \mathrm{~S}-\mathrm{OH}-$ chol or T0901317 was added during the equilibration step. Cells were washed once with prewarmed $0.1 \%$ BSA/DMEM before the start of the efflux incubations. Sterol acceptors (i.e., apoA-I, HDL, apoE2, or apoE4) were added in $0.1 \%$ BSA/DMEM medium at the indicated concentrations. In ABCA1-inhibition experiments, probucol or glyburide were added as indicated in the text or the figure legends. At the indicated times, media were collected and centrifuged at $4000 \mathrm{rpm}$ to remove cellular debris. Remaining cells were washed four times in cold PBS and lysed with PBS/1\% Triton X-100. Aliquots of cell lysates and media were then analyzed in a liquid scintillation counter (Tri-carb 2100TR). Radioactivity was measured as disintegrations per minute (DPM) and cellular cholesterol efflux was calculated using the following equation:

$$
\begin{aligned}
\% \text { total efflux }= & \mathrm{DPM}_{\text {media }} \times 100 /\left(\mathrm{DPM}_{\text {media }}\right. \\
& \left.+\mathrm{DPM}_{\text {cell lysate }}\right) .
\end{aligned}
$$

Each assay was performed using three wells and each experiment was performed twice.

For inhibition studies, the result is calculated using the following formula:

$\%$ apo- or HDL-mediated cholesterol $=(\%$ total efflux, with acceptor, 24S-OH-chol and inhibitor- $\%$ total Efflux with acceptor only) $\times 100 /(\%$ total efflux with acceptor, $24 \mathrm{~S}-\mathrm{OH}$-chol-\% total Efflux with acceptor only).

\section{Cell death}

At a confluency of $60-80 \%$, pericytes were cultured in $1 \mathrm{~mL} 0.1 \% \mathrm{BSA} / \mathrm{DMEM}$ and treated with different concentrations of 24S-OH-chol or T0901317 for $24 \mathrm{~h}$ or glyburide or probucol for $8 \mathrm{~h}$ (corresponding to the incubation time during the cholesterol release experiments). For $A \beta_{40}$ and $A \beta_{42}$ peptide toxicity, pericytes were cultured in $1 \mathrm{~mL} 0.5 \% \mathrm{BSA} / \mathrm{DMEM}$ and treated with different concentrations of these peptides ( 0 to $120 \mathrm{nM}$ ) for $3 \mathrm{~h}$ (corresponding to the incubation time during the cellular accumulation) and $24 \mathrm{~h}$. Cell viability was then measured using CytoToxONE Homogeneous Membrane integrity assay ${ }^{\circledR}$ kit (Promega, Madison, WI, USA), according to the manufacturer's recommendations. This assay rapidly measures the release of LDH from cells with a damaged membrane. Colorimetric values were measured using a fluorescence spectrophotometer (Hitachi, Tokyo, Japan) and the results represent the percentage of dead cells compared with the total lysis values (using the kit's lysis buffer to permeabilize cells).

\section{Cellular $A \beta_{40}$ and $A \beta_{42}$ peptide accumulation}

Pericytes were pre-treated with 24S-OH-chol for $24 \mathrm{~h}$ and rinsed for $10 \mathrm{~min}$ with $\mathrm{RH} / 0.5 \%$ BSA buffer. Cells were then incubated in the presence of $12 \mathrm{nM}$ $\left[{ }^{3} \mathrm{H}\right]$ inulin or $A \beta_{40}$ or $A \beta_{42}$ peptides with gentle agitation at $37^{\circ} \mathrm{C}$. At the indicated times, cells were washed four times with cold PBS and were lysed using RIPA buffer supplemented with protease inhibitor cocktails (Sigma). The lysate's protein concentration was assayed using the Bradford method, as described above. $\left[{ }^{3} \mathrm{H}\right]$ inulin was measured using a liquid scintillation counter (Tri-carb 2100TR) and A $\beta$ peptides were quantified with commercially available ELISA kits (Invitrogen), according to the manufacturer's recommendations. The results correspond to the amount of accumulated inulin (in DPM) or A $\beta$ peptides (in pg) in cell divided by the amount of protein (in $\mu \mathrm{g}$ ).

\section{Statistical analysis}

Data were analyzed for statistical significance using one-way analysis of variance (ANOVA) followed by appropriate posthoc tests. As indicated, all data represent the mean \pm s.d. or the mean \pm s.e.m. Statistical analysis was performed with Prism software (version 5.0 from GraphPad Software Inc., San Diego, CA, USA).

\section{RESULTS}

\section{Brain pericytes characterization in vitro}

Figure 1A shows the characteristic aspect of brain pericyte cultures. According to this picture and our previous study [32], brain pericytes showed numerous tiny projections. $\alpha$-SMA and NG2 are markers of pericytes and were used to their characterization (Fig. 1B and C, respectively). As described in our previous study [32], no vascular smooth muscle cells (SMCs) was observed (i.e., SMCs were thinner and more elongated). No staining was observed after the use of the von Willebrand factor antibody confirming that pericytes were not contaminated by BCECs. 

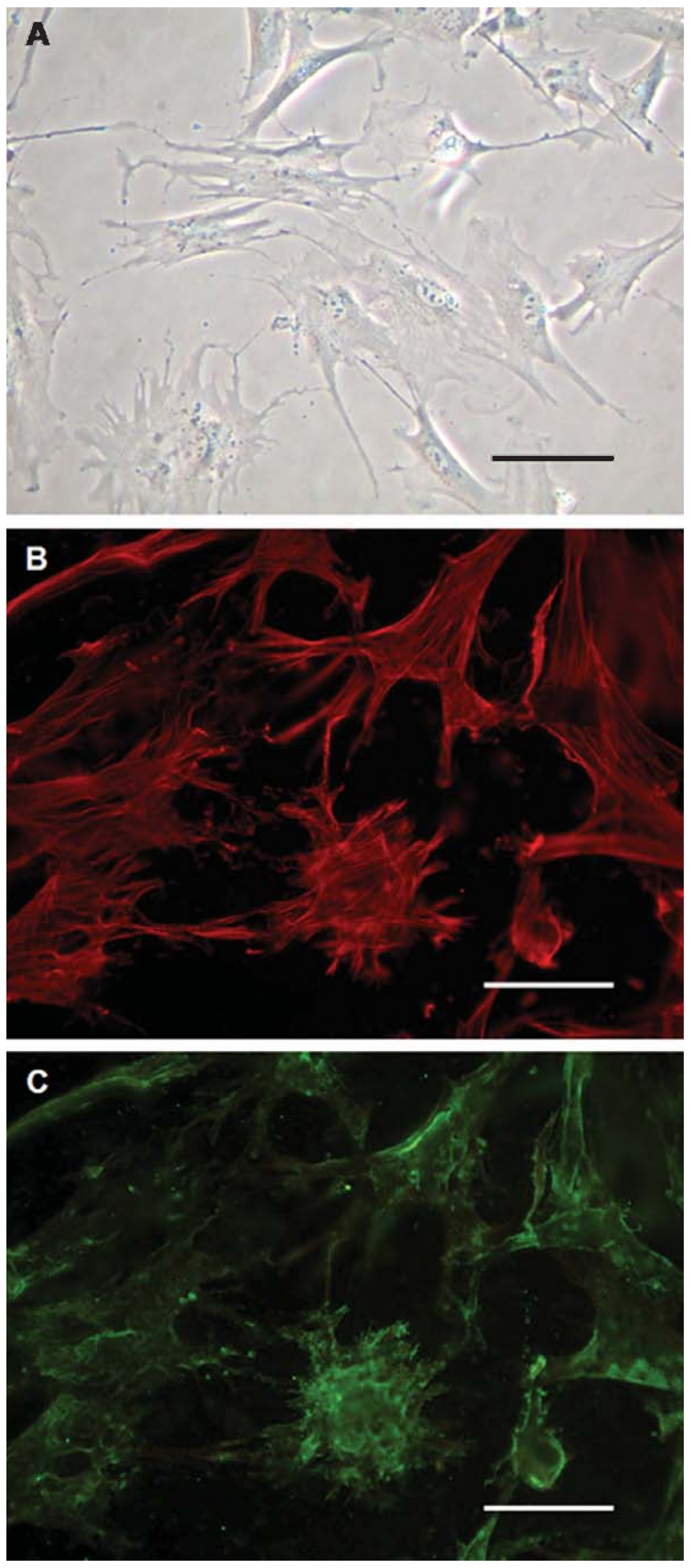

Fig. 1. Phase-contrast micrograph of brain pericyte culture (A) and double immunostaining for alpha-smooth muscle actin (B) and Neuron-Glial 2 (C). Bars, $50 \mu \mathrm{m}$.

Brain pericytes express $L X R$ s and $A B C A 1$ and release cholesterol to apoE and HDL particles

An RT-PCR technique was first used to highlight pericyte-specific expression patterns of LXRs and their target genes (such as $A B C A 1$ and $A B C G 1$ ). The pericyte mRNAs were then compared with bovine liver extract and bovine BCEC mRNAs. Primers and conditions used to amplify these mRNA are listed in Table 1. As shown in Fig. 2A, pericytes, and liver extract express $L X R s$ and $A B C A 1$, but not $A B C G 1$. The latter is known to be expressed by BCECs [27]. Expression of these protagonists in reverse cholesterol transfer results in the ability to transfer cholesterol (Fig. 2B) preferentially to HDL particles $(2.40 \pm 0.22 \%$ in the absence of HDL particles versus $14.05 \pm 0.85 \%$ in the presence of HDL) and to apoE-lipid free particles $(11.73 \pm 0.30 \%$ and $12.49 \pm 0.17 \%$ in the presence of apoE2 and apoE4, respectively). Interestingly, there was no significant difference between apoE2 and apoE4 in terms of their respective abilities to stimulate cholesterol efflux. The presence of apoA-I did not significantly influence this efflux $(2.40 \pm 0.22 \%$ when present versus $2.37 \pm 0.38 \%$ when absent).

At present, little is known about the mechanisms underlying the diffusion of $24 \mathrm{~S}-\mathrm{OH}$-chol across cell membranes. Thus, in order to clarify the putative contributions of HDL and the major apolipoproteins found in the central nervous system (apoE and apoA-I) in this process, we performed efflux assays using radioactive $24 \mathrm{~S}-\mathrm{OH}$-chol. Brain pericytes were loaded with $24 \mathrm{~S}-\mathrm{OH}$-chol and subsequent oxysterol efflux was measured over $3 \mathrm{~h}$ (Fig. 2C and D) in the presence or absence of cholesterol acceptors. Whereas lipidfree apoA-I (Fig. 2C), apoE2, and apoE4 (Fig. 2D) was found to have no effect on efflux (compared with the control), a significant increase in efflux was measured in the presence of HDL $(32.31 \pm 1.26 \%$ versus $43.99 \pm 1.56 \%$ of cellular radioactivity at $180 \mathrm{~min}$ the absence and presence of HDL, respectively).

\section{Expression of ABCA1 (but not LXRs/ABCG1) is modulated by LXR agonists}

Given that interfering with cholesterol metabolism in primary pericyte cultures induces apoptosis [34], we first measured cell death with different concentrations of the natural LXR agonist (24S$\mathrm{OH}$-chol) and a synthetic LXR agonist (T0901317). Under our culture conditions, an increase in the percentage of apoptosis was observed after $24 \mathrm{~h}$ of treatment with $50 \mu \mathrm{M} 24 \mathrm{~S}-\mathrm{OH}$-chol and with T0901317 (supplementary Figure 1; available online: http://www.j-alz.com/issues/30/vol30-3. html\#supplementarydata01), with $7.96 \pm 0.21 \%$ and $19.10 \pm 0.67 \%$ of apoptotic cells, respectively (versus $3.15 \pm 0.07 \%$ for the control, DMSO-treated condition). To avoid cell death in subsequent experiments, 

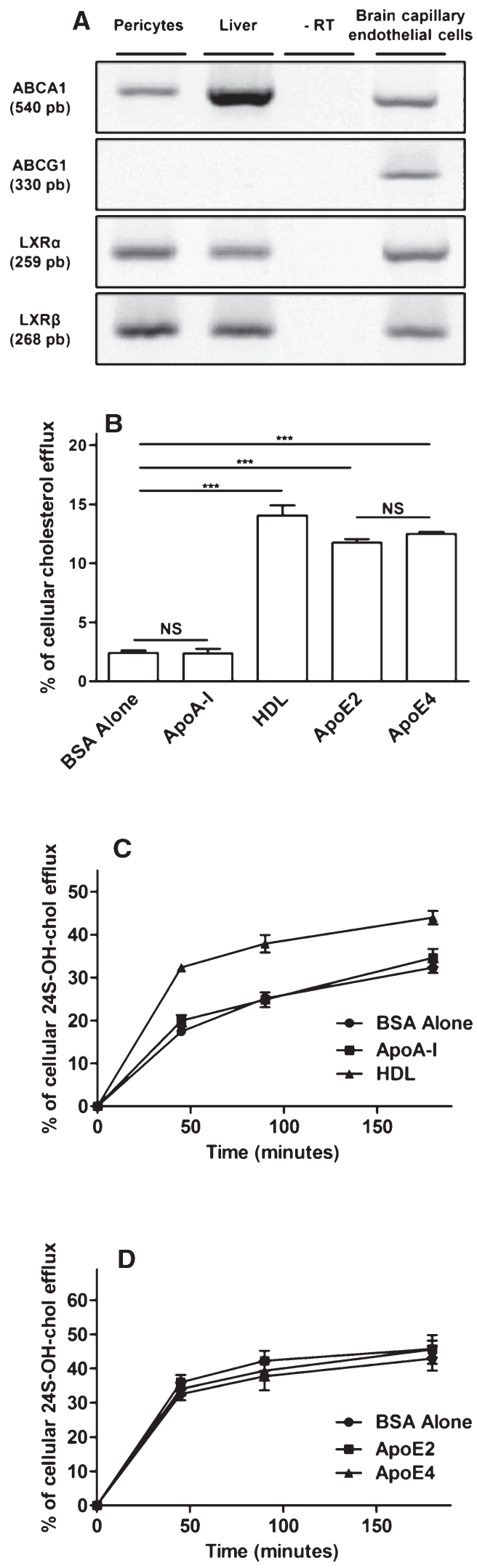

we did not exceed an LXR agonist concentration of $10 \mu \mathrm{M}$.

Next, the expression of LXRs, ABCA1, and ABCG1 were investigated by RT-PCR and immunoblot techniques after $24 \mathrm{~h}$ of treatment with LXR agonists. Transcriptional and protein levels of ABCA1 were dose-dependently increased by LXR agonists (Fig. 3A and $\mathrm{D}$, respectively), whereas no significant variations were observed for LXRs (Fig. 3B-D). Consistently with the absence of transcriptional expression of $A B C G 1$ (Fig. 2A), protein levels of ABCG1 were not detected after treatment with agonists (data not shown). Similar results were found after 6 and $12 \mathrm{~h}$ of treatment (data not shown). Since ABCA1 is a transmembrane transporter, we then explored protein levels in membrane-enriched samples. After $24 \mathrm{~h}$ of treatment (DMSO, $10 \mu \mathrm{M}$ T0901317 or 24S-OH-chol), an increase in ABCA1 membrane protein content was observed (Fig. 3E). The protein level of Scavenger receptor class B member 1 (SCARB1, a receptor whose transcriptional expression is not controlled by the LXR pathway in pericytes) (data not shown) was used as loading control.

The increase in ABCAl expression at the pericyte membrane correlates with an increase in apoE-, apoA-I-, and HDL-mediated cholesterol efflux from brain pericytes

To investigate the consequences of the increase in ABCA1 expression after 24S-OH-chol or T0901317 treatment, brain pericytes were labeled with radioactive cholesterol. Lipid-free apoE-, apoA-I-, and HDL-mediated cholesterol release was then measured.

Fig. 2. Expression of protagonists in reverse cholesterol transfer in bovine brain pericytes (A) and the effects of apoA-I, HDL, apoE2, and apoE4 on cellular cholesterol (B) or 24S-OHhydroxycholesterol (C and D) efflux. A) Expression of $A B C A 1$, $A B C G 1$, and $L X R s$ were analyzed by RT-PCR analysis. Bovine liver extract was used as positive control (except for Abcgl, which is expressed in brain capillary endothelial cells, as previously described [27]). The primers and assays conditions are listed in Table 1. B) Cells were radiolabeled with $\left[{ }^{3} \mathrm{H}\right]$ cholesterol $(0.5 \mu \mathrm{Ci} / \mathrm{mL}$ for $36 \mathrm{~h})$ before incubation for $8 \mathrm{~h}$ with $0.1 \% \mathrm{BSA}$ or in the presence of apoA-I $(20 \mu \mathrm{g} / \mathrm{mL})$, apoE2 $(20 \mu \mathrm{g} / \mathrm{mL})$, apoE4 $(20 \mu \mathrm{g} / \mathrm{mL})$, or HDL $(25 \mu \mathrm{g} / \mathrm{mL})$. Cholesterol efflux was calculated as described in the Materials and Methods section. NS: non-significant; ${ }^{* * *} p<0.001$ in one way ANOVA followed by Dunnett's test, when compared with BSA alone. C, D) Cells were labeled with radioactive $24 \mathrm{~S}-\mathrm{OH}-\mathrm{chol}$ $(0.1 \mu \mathrm{Ci} / \mathrm{mL}$ for $14 \mathrm{~h})$ and subsequently, efflux was measured at indicated times in the presence of $0.1 \%$ BSA, apoA-I $(20 \mu \mathrm{g} / \mathrm{mL})$, apoE2 $(20 \mu \mathrm{g} / \mathrm{mL})$, apoE4 $(20 \mu \mathrm{g} / \mathrm{mL})$, or HDL $(25 \mu \mathrm{g} / \mathrm{mL}) . \mathrm{B}, \mathrm{C}$, and D show the means \pm s.d. of one experiment performed in triplicate and are representative of two independent experiments. 

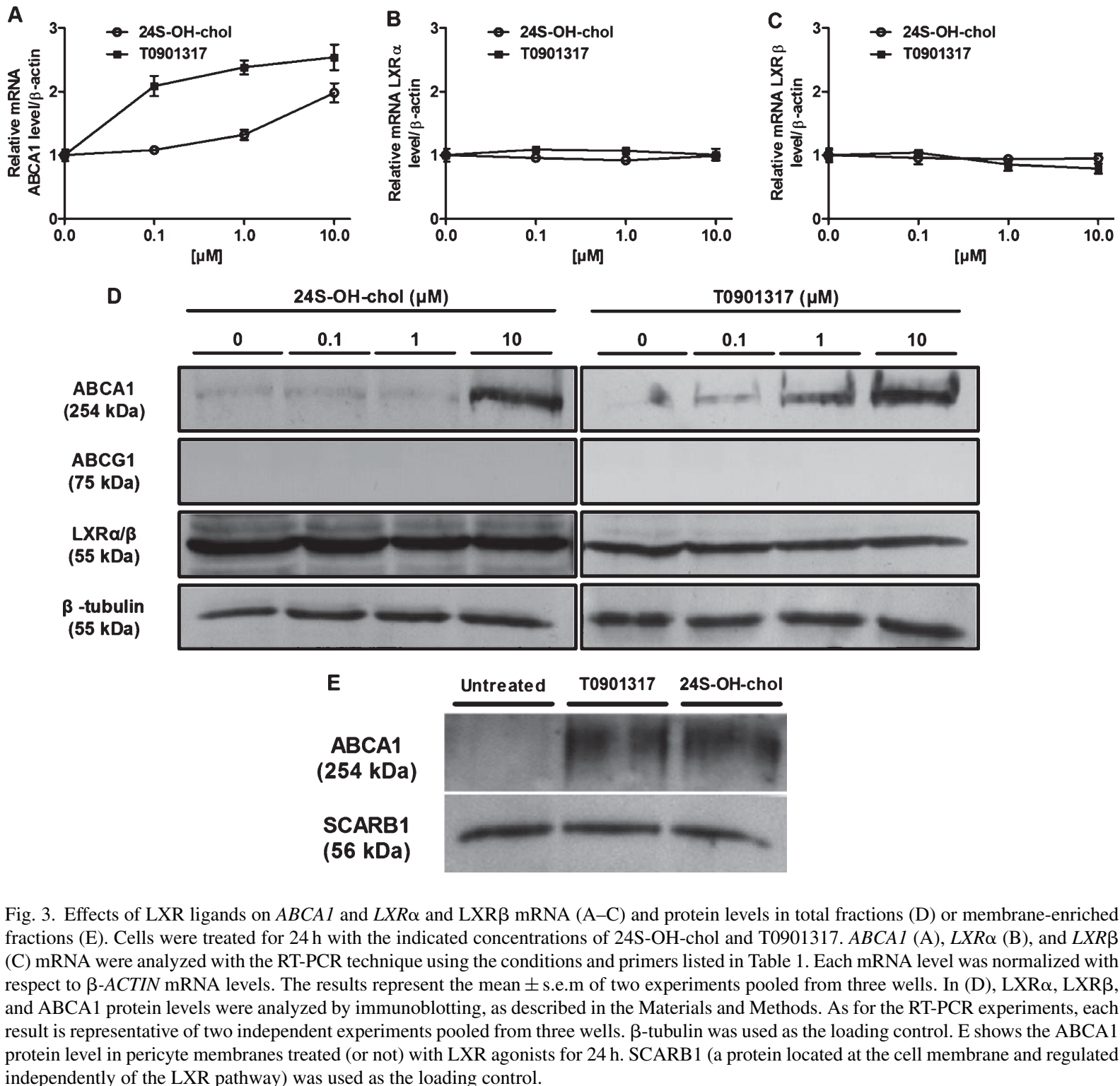

Fig. 3. Effects of LXR ligands on $A B C A 1$ and $L X R \alpha$ and LXR $\beta$ mRNA (A-C) and protein levels in total fractions (D) or membrane-enriched fractions (E). Cells were treated for $24 \mathrm{~h}$ with the indicated concentrations of $24 \mathrm{~S}-\mathrm{OH}$-chol and T0901317. ABCA1 (A), LXR $\alpha$ (B), and $L X R \beta$ (C) mRNA were analyzed with the RT-PCR technique using the conditions and primers listed in Table 1. Each mRNA level was normalized with respect to $\beta$-ACTIN mRNA levels. The results represent the mean \pm s.e.m of two experiments pooled from three wells. In (D), LXR $\alpha, \mathrm{LXR} \beta$, and ABCA1 protein levels were analyzed by immunoblotting, as described in the Materials and Methods. As for the RT-PCR experiments, each result is representative of two independent experiments pooled from three wells. $\beta$-tubulin was used as the loading control. E shows the ABCA1 protein level in pericyte membranes treated (or not) with LXR agonists for $24 \mathrm{~h}$. SCARB1 (a protein located at the cell membrane and regulated independently of the LXR pathway) was used as the loading control.

Figure 4A shows that treatment of cells with $10 \mu \mathrm{M} 24 \mathrm{~S}-\mathrm{OH}-\mathrm{chol}$ for $24 \mathrm{~h}$ significantly increased cholesterol efflux, compared with the control (BSAonly) condition (2-fold, from $4.80 \pm 1.33 \%$ to $10.45 \pm 1.01 \%)$. When the cholesterol acceptor apoA-I alone was present, no significant increase in efflux was observed (from $4.80 \pm 1.33 \%$ to $5.23 \pm 1.31 \%$ ). Treatments with 24S-OH-chol and T0901317 increased this efflux to $13.99 \pm 1.34 \%$ and $15.67 \pm 0.97 \%$, respectively. Similar experiments performed with HDL particles and lipid-free apoE2 or lipid-free apoE4 show similar results (Fig. $4 \mathrm{~B}$ and $\mathrm{C}$ ). In the presence of HDL particles, the cholesterol efflux was almost $35.08 \pm 2.55 \%$ and increased to $46.61 \pm 2.00 \%$ when the cells were treated with $24 \mathrm{~S}-\mathrm{OH}$-chol for $24 \mathrm{~h}$. The transfer is also increased in the presence of lipid-free apoE2 and apoE4 $(11.09 \pm 0.34 \%$ and $11.42 \pm 0.52 \%$ without agonists, respectively, compared with $15.68 \pm 0.79 \%$ and $16.99 \pm 0.99 \%$ for treatment with $10 \mu \mathrm{M} 24 \mathrm{~S}-\mathrm{OH}$-chol). Interestingly, there was no significant difference in cholesterol efflux in the presence of lipid-free apoE2 versus apoE4 (Fig. 4C). 


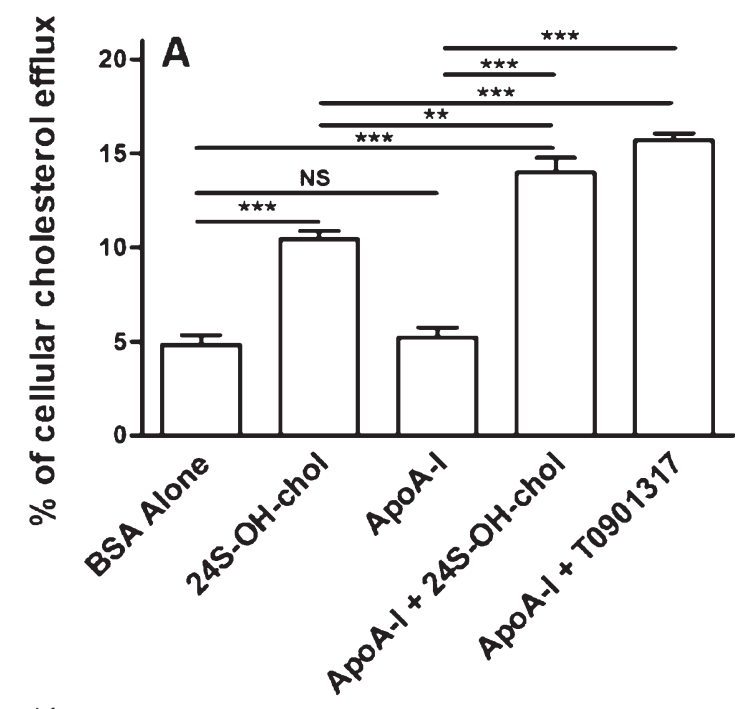

\section{ABCA1-inhibition decreases cholesterol efflux to apoA-I, apoE, and HDL particles}

To confirm the relationship between the increase in ABCA1 expression observed in Fig. 3 and the increase in cholesterol release observed in Fig. 4, we performed experiments in the presence of the ABCA1 inhibitors probucol and glyburide [35-37]. As shown by the results of a lactate dehydrogenase (LDH) activity assay (supplementary Figures 2A and $\mathrm{B}$, respectively), these molecules were not toxic for pericytes (at least under our experimental conditions). Cellular cholesterol efflux experiments were then performed as described above but with the addition of $10 \mu \mathrm{M}$ probucol or $100 \mu \mathrm{M}$ glyburide. Figure $5 \mathrm{~A}$ shows that the apoA-I- and HDL-mediated cholesterol efflux induced by the $24 \mathrm{~S}-\mathrm{OH}$-chol treatment was completely abolished by the presence of $10 \mu \mathrm{M}$ probucol $(10.73 \pm 0.45 \%$ versus $3.70 \pm 0.22 \%$ and $13.55 \pm 0.35 \%$ versus $9.20 \pm 0.41 \%$, respectively). Similar observations were made for lipid-free apoE-mediated cholesterol efflux (14.77 $\pm 1.29 \%$ versus $10.89 \pm 1.24 \%$ and $14.57 \pm 1.39 \%$ versus $9.6 \pm 0.71 \%$ for apoE2 and apoE4, respectively). This inhibition was dose-dependent, as shown in Fig. 5B. Glyburide appears to be less efficient than probucol in inhibiting ABCA1-mediated cholesterol efflux to lipid-free apoA-I, apoE, and HDL (Fig. 5C). No significant inhibition was observed for HDL and lipid-free apoE $(26.32 \pm 1.40 \%$ versus $23.47 \pm 2.18 \%, 19.68 \pm 1.23 \%$ versus $18.39 \pm 0.54 \%$ and $19.83 \pm 1.24 \%$ versus $19.29 \pm 1.05 \%$ for HDL, apoE2 and apoE4, respectively). However, apoA-Imediated cholesterol efflux was partially inhibited $(22.14 \pm 1.61 \%$ versus $14.49 \pm 1.07 \%)$. The results of dose-dependent inhibition experiments (Fig. 5D) confirmed these observations and suggested that glyburide efficiently inhibits apoA-I- and HDL-mediated cholesterol efflux, whereas cholesterol release to apoE seems

Fig. 4. Effect of LXR ligands on apoA-I-, apoE-, and HDL-mediated cholesterol release from primary bovine brain pericytes. Cells were labelled with $\left[{ }^{3} \mathrm{H}\right]$ cholesterol $(0.5 \mu \mathrm{Ci} / \mathrm{mL}$ for 36 hours $)$ and were then equilibrated for $24 \mathrm{~h}$ at $37^{\circ} \mathrm{C}$ in $0.1 \%$ BSA/DMEM containing either DMSO (control) or $10 \mu \mathrm{M} 24 \mathrm{~S}-\mathrm{OH}-\mathrm{chol}$ or $10 \mu \mathrm{M}$ T0901317. Cellular cholesterol release into the medium was determined after incubation with either $20 \mu \mathrm{g} / \mathrm{mL}$ apoA-I (A), $25 \mu \mathrm{g} / \mathrm{mL}$ $\mathrm{HDL}$ (B) or $20 \mu \mathrm{g} / \mathrm{mL}$ apoE2/E4 (C) for $8 \mathrm{~h}$ at $37^{\circ} \mathrm{C}$. Each bar represents the means \pm s.e.m. $(n=6-9)$. NS: non-significant; ${ }^{* *} p<0.01$; ${ }^{* * *} p<0.001$ : significantly different from the selected condition, according to one way ANOVA followed by Bonferroni's multiple comparison test. 

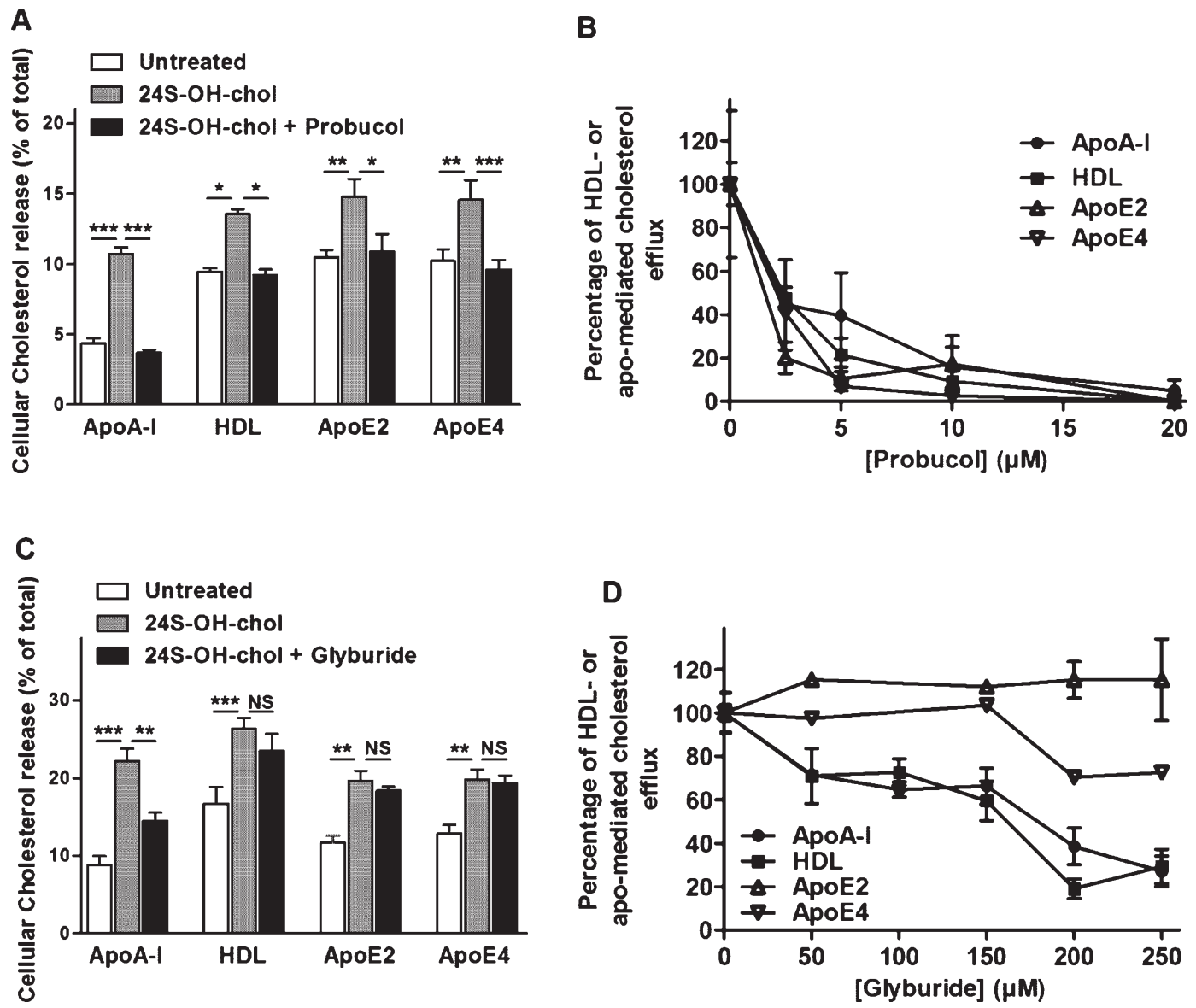

Fig. 5. Inhibition by probucol and glyburide of cholesterol efflux induced by $24 \mathrm{~S}-\mathrm{OH}$-chol. Cells were labeled with radioactive cholesterol as described in the Materials and Methods section. A, C) During the equilibration step, pericytes were treated with DMSO (control) or 10 $\mu$ M $24 S-$ $\mathrm{OH}$-chol. When indicated, the ABCA1 inhibitor $(10 \mu \mathrm{M}$ probucol $(\mathrm{A})$ or $100 \mu \mathrm{M}$ glyburide $(\mathrm{C})[23,35,36])$ was added to the efflux experiment performed in the presence of apoA-I $(20 \mu \mathrm{g} / \mathrm{mL})$, HDL $(25 \mu \mathrm{g} / \mathrm{mL})$, apoE2 $(20 \mu \mathrm{g} / \mathrm{mL})$, or apoE4 $(20 \mu \mathrm{g} / \mathrm{mL})$. After $8 \mathrm{~h}$ of incubation, total cholesterol content and release were measured as described in the Materials and Methods section. Each bar represents the means \pm s.d. $(n=3)$ of a one of three representative experiments. NS: non-significant; ${ }^{*} p<0.05 ;{ }^{* *} p<0.01 ;{ }^{* * *} p<0.001$ : significantly different from the selected condition, using one way ANOVA followed by Bonferroni's multiple comparison test. B,D) During the equilibration step, pericytes were pretreated with $10 \mu \mathrm{M} 24 \mathrm{~S}-\mathrm{OH}$-chol. After washing, apoA-I $(20 \mu \mathrm{g} / \mathrm{mL}), \mathrm{HDL}(25 \mu \mathrm{g} / \mathrm{mL})$, apoE2 $(20 \mu \mathrm{g} / \mathrm{mL})$, or apoE4 $(20 \mu \mathrm{g} / \mathrm{mL}) \mathrm{was}$ added to the cholesterol efflux medium containing different concentrations of probucol (B) and glyburide (D). Total cholesterol content and release were then measured as described in the Materials and Methods section. Results represent the apo- or HDL-mediated cholesterol efflux and were calculated as described in the Materials and Methods section. For each concentration, the results represent the mean \pm s.d. for one of three representative experiments.

to be unaffected (lipid-free apoE2) or only slightly reduced (lipid-free apoE4).

\section{Pericyte accumulation of $A \beta$ peptides is not} modified by treatment with $24 \mathrm{~S}$-OH-chol

It was previously hypothesized that $\mathrm{ABCA} 1$ may be involved in the $A \beta$ peptide transport across the BBB [38, 39]. These peptides first encounter pericytes before elimination through the $\mathrm{BBB}$ and it has previously been shown that brain pericytes are able to internalize these peptides [40]. Given that brain pericytes express ABCA1 (our present results and [27]), we decided to investigate the influence of $24 \mathrm{~S}-\mathrm{OH}$ chol on $A \beta$ peptide accumulation by pericytes. Cells were pre-treated for $24 \mathrm{~h}$ with $10 \mu \mathrm{M} 24 \mathrm{~S}-\mathrm{OH}$-chol or vehicle and subsequent $A \beta$ peptide accumulation was quantified at different time points. Figure 6A shows that $A \beta_{40}$ and $A \beta_{42}$ peptide accumulation was not modified by $24 \mathrm{~S}-\mathrm{OH}-\mathrm{chol}$ treatment, compared with 

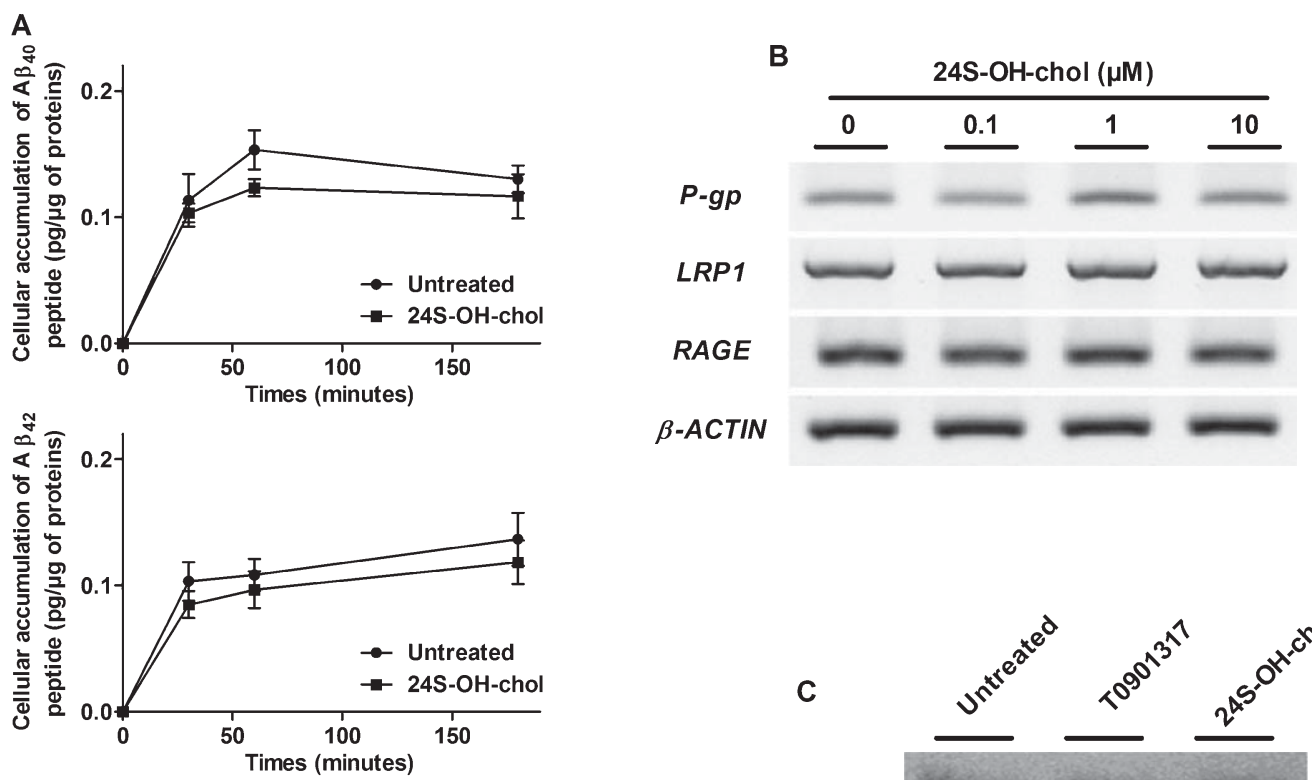

$\beta$-ACTIN
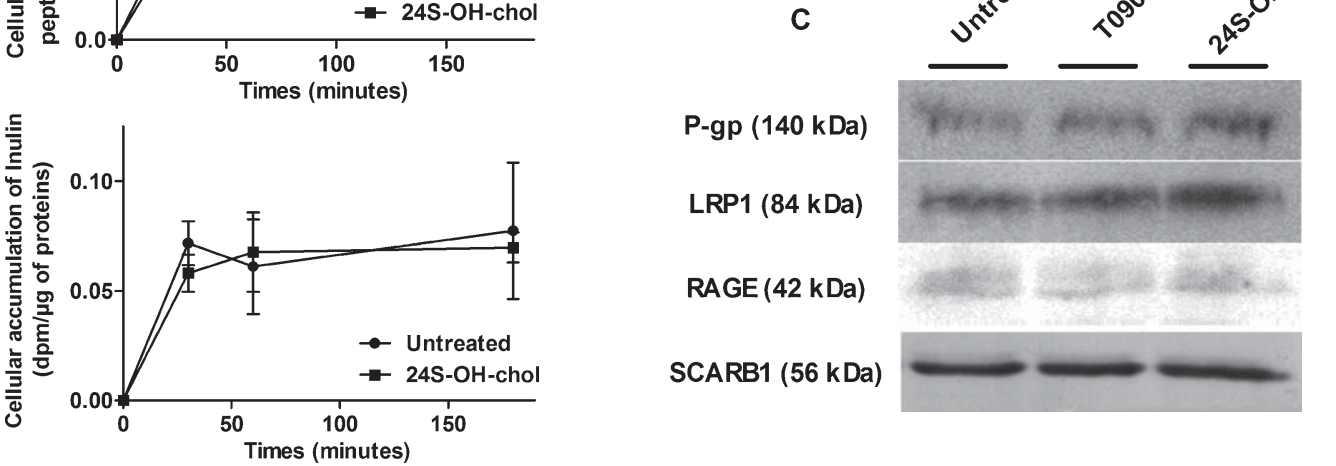

Fig. 6. Effects of $24 \mathrm{~S}-\mathrm{OH}$-chol on A $\beta$ peptide accumulation. Pericytes were pre-treated for $24 \mathrm{~h}$ with DMSO (control) or $24 \mathrm{~S}-\mathrm{OH}$-chol $(10 \mu \mathrm{M})$. A) Cells were incubated for the indicated periods with $A \beta_{40}$ (top panel) or $A \beta_{42}$ (middle panel) peptides or with $\left[{ }^{3} \mathrm{H}\right]$ inulin (bottom panel) with gentle agitation at $37^{\circ} \mathrm{C}$. As indicated, cells were lysed and the accumulation of $\mathrm{A} \beta$ peptides or $\left[{ }^{3} \mathrm{H}\right]$ inulin was measured. B) After $24 \mathrm{~h}$ of treatment with different concentrations of $24 \mathrm{~S}-\mathrm{OH}$-chol, pericytes were lysed and the transcriptional expression of $L R P 1, R A G E$, and $P$ - $g p$ was assayed using the primers and conditions listed in Table 1. $\beta-A C T I N(179 \mathrm{pb})$ was used as loading control. C) Protein levels of LRP1, RAGE P-pg, and SCARB1 in membrane-enriched fractions were investigated with immunoblot techniques. Before lysis, pericytes were treated with DMSO (control) or with $10 \mu \mathrm{M}$ T0901317 or $10 \mu \mathrm{M} 24 \mathrm{~S}-\mathrm{OH}-$ chol for $24 \mathrm{~h}$. Proteins were extracted as described in the Materials and Methods section. Each result is representative of two independent experiments. SCARB1 was used as loading control.

the untreated condition. Inulin has much the same molecular weight as $\mathrm{A} \beta$ peptides (almost $4.5 \mathrm{kDa}$ ) and was used as a control. No significant difference in accumulation was observed in the presence of $10 \mu \mathrm{M} 24 \mathrm{~S}-\mathrm{OH}$-chol. These results suggest that ABCA1 is not directly involved in $A \beta$ peptide accumulation by brain pericytes. Inhibition of ABCA1 with either probucol or glyburide prompted the same conclusion (data not shown). As high concentrations of $\mathrm{A} \beta$ peptides are toxic for brain pericytes $(25 \mu \mathrm{M}$ [41] and $10 \mu \mathrm{M}$ [40], respectively), we then measured cell death with different concentrations of $A \beta$ peptides ( 0 to $120 \mathrm{nM}$ ) corresponding to our accumulation experiments $(12 \mathrm{nM})$. Under our culture conditions, no increase in the percentage of apoptosis was observed after 3 or $24 \mathrm{~h}$ of treatment (supplementary Figure 3A and $B$, for respectively $A \beta_{40}$ and $A \beta_{42}$ ).

Pericytes are known to express receptors and transporters involved in $A \beta$ accumulation, such as lowdensity lipoprotein receptor-related protein 1 (LRP1), receptor for advanced glycation end-products (RAGE), and P-glycoprotein (P-gp) [27, 42]. We therefore tested the effects of $24 \mathrm{~S}-\mathrm{OH}$-chol on transcriptional and protein expression levels of these proteins. As shown respectively by Fig. 6B and $\mathrm{C}$, neither transcriptional nor protein levels of LRP1, RAGE, and P-gp in membrane-enriched fractions were modified by treatment with $24 \mathrm{~S}-\mathrm{OH}$-chol. 


\section{DISCUSSION}

In recent years, a number of studies have highlighted the major role of $24 \mathrm{~S}-\mathrm{OH}$-chol in brain cholesterol homeostasis and neurodegenerative diseases such as $\mathrm{AD}$ (reviewed in [43]). This oxysterol is the major metabolite of cholesterol and is a natural agonist for the LXR nuclear receptors expressed by neural cells (neurons and glial cells) and the BCECs composing the BBB. In these different cell types, the LXR nuclear receptors regulate the expression of ABCA1 and ABCG1, both of which are involved in the complex process of brain cholesterol homeostasis $[8,9,11$, $28,29]$. These observations reinforce the hypothesis whereby the BBB participates actively in the regulation of cholesterol metabolism in the brain. It has been estimated that 6 to $7 \mathrm{mg}$ of $24 \mathrm{~S}-\mathrm{OH}$-chol is eliminated per day from the brain into the systemic circulation across the huge surface area (approx. $20 \mathrm{~m}^{2}$ ) represented by the BBB $[4,5]$. Before crossing this barrier, $24 \mathrm{~S}-\mathrm{OH}-\mathrm{chol}$ encounters brain pericytes embedded in the basal lamina. Although these cells are essential for the establishment and maintenance of BBB function [26], their role in brain cholesterol homeostasis has yet to be characterized (in contrast to that of the BCECs).

To this end, we first addressed the effects of 24S$\mathrm{OH}$-chol on cholesterol efflux from brain pericytes. Our results suggest that $24 \mathrm{~S}-\mathrm{OH}-\mathrm{chol}$ may influence the cellular cholesterol efflux from brain pericytes to HDL, apoE-, and apoA-I-lipid free particles via an exclusively ABCA1-dependent pathway (given the lack of expression of $A B C G 1$ [27]). However, ABCA1 inhibition experiments with glyburide and probucol yielded partially divergent results. Whereas probucol completely blocked efflux to apoE, apoA-I, and HDL, glyburide only decreased apoA-I and HDL-mediated cholesterol release. This discrepancy may be related to the inhibitors' respective mechanisms of action. Glyburide is known to compete with apoA-I for binding to ABCA1 [44] and an effect on apoE-mediated efflux has never been reported. Probucol inhibits ABCA1's function and reduces its stability [45]. These data suggest that the mechanisms of cholesterol release may differ; to accept cholesterol from ABCA1, apoA-I/HDL particles may need to interact with the transporter itself, whereas apoE lipid-free particles may need to interact with receptors (particularly members of the LRP family expressed in pericytes [27]). We failed to observe an autoregulation of $\operatorname{LXR} \alpha$ and LXR $\beta$ expression. This autoregulation process was previously described in human cells but was absent in murine and, more recently, in rat cells [10]. As recently suggested [46], it is likely that the autoregulation of LXR expression by oxysterols is cell type-, tissue-, and species-dependent.

The details of cellular cholesterol release are still obscure. The process seems to be cell type- and apolipoprotein-dependent. In macrophages, ABCG1 and ABCA1 seem to act sequentially to mediate the efficient removal of excess cellular cholesterol to apoA-I and HDL particles [47]. In murine brain tissue, however, ABCG1 mediates cholesterol release from cerebellar astroglia without any involvement of ABCA1 [9]. Our results suggest that in brain pericytes, ABCA1 alone is sufficient to remove excess cholesterol to apoE, apoA-I, and HDL.

It is especially noteworthy that we never observed any lipid-free apoE isoform-dependent lipid efflux. However, the apoE4 isoform represents a strong factor in the development of $\mathrm{AD}$ [48], when compared with apoE2 or apoE3. It was initially suggested that apoE2 has a greater ability than apoE3 and apoE4 to accept cellular cholesterol from neurons and astrocytes [49]. However, these conclusions seem to be study- and cell type-dependent. In accordance with our results, it has been reported that the different isoforms were equally potent in their ability to bind ABCA1 [50] and to stimulate cholesterol efflux in neurons, fibroblasts, and plexus choroids cells [11, 13, 50]. These discrepancies show that the details of apoEisoform-dependent lipoprotein generation remain to be elucidated. Another hypothesis suggests that these isoforms primarily influence $A \beta$ peptide clearance from the brain [51,52]. Overall, our results suggest that brain pericytes may contribute to the generation/lipidation of HDL/HDL-like particles in the brain and/or the circulation and so may be involved in brain cholesterol homeostasis.

Our data must be taken into account in this respect. It is now clear that the LXR/ABCA1 axis represents a promising therapeutic target in AD. Indeed, 24S-OHchol, LXR nuclear receptors, ABCA1, HDL, apoE, and apoA-I are key players in not only brain cholesterol homeostasis but also amyloid accumulation and deposition. It has already been demonstrated that $24 \mathrm{~S}$ $\mathrm{OH}$-chol and synthetic LXR agonists decrease the brain accumulation/deposition of $A \beta$ peptides and alleviate cognitive impairment in $\mathrm{AD}$ transgenic mice [15-17, 53, 54]. Furthermore, Abcal-overexpressing $\mathrm{AD}$ mice show a decrease in amyloid burden [55], whereas Abcal deficiency promotes deposition [56-58]. In view of these findings and the fact that $A \beta$ peptides are cleared across the $\mathrm{BBB}$, it was recently suggested that the ABCA1 expressed by BCECs is directly involved in $A \beta$ peptide efflux from the brain 
through the BBB $[38,59]$. Since brain pericytes internalize $A \beta$ peptides and help to transport these peptides from the brain to the blood [40], we hypothesized that $24 \mathrm{~S}-\mathrm{OH}-\mathrm{chol}$ may influence this activity. We looked at whether 24S-OH-chol treatment modulates the expression of receptors or transporters (such as LRP1, RAGE, and $\mathrm{P}$-gp) involved in $\mathrm{A} \beta$ peptide uptake and transport across the BBB [24]. These proteins are reportedly expressed by human and bovine brain pericytes [27, $42,60]$. Our results suggest that the expression pattern of these proteins is not changed by $24 \mathrm{~S}-\mathrm{OH}-\mathrm{chol}$ treatment. Moreover, although an increase in ABCA1 expression after $24 \mathrm{~S}-\mathrm{OH}$-chol treatment was observed, it did not correlate with a change in $A \beta_{40}$ and $A \beta_{42}$ peptide accumulation inside pericytes. In accordance with a previous study in $a b c a 1^{-/}-$-transgenic mice (in which no modification of $A \beta_{40}$ peptide efflux across the $\mathrm{BBB}$ was observed) [38], our results suggest that $A B C A 1$ is not directly involved in naive $A \beta$ peptide uptake and transport across the BBB. However, the in vivo situation seems more complicated. Indeed, in the brain interstitial fluid, the $A \beta$ peptides may interact with LRP1, $\alpha 2$ macroglobulin, apoE, and others apolipoproteins (apoJ) which influence $A \beta$ deposition, uptake, and clearance across the BBB [61]. As in our study we only have focused on naíve form of $A \beta$ peptides, we suggest that cellular accumulation of these complexes could also be considered and that $24 \mathrm{~S}-\mathrm{OH}-$ chol effects on their clearance must be investigated.

Since cholesterol transfer to apolipoproteins and HDL particles is the major function of ABCA1, it is likely that $\mathrm{A} \beta$ peptide deposition/elimination depends on the lipidation status of cerebral lipoproteins. Further investigations are then required to clarify the exact mechanism by which ABCA1 decreases brain $\mathrm{A} \beta$ peptide accumulation in brain and to explore the consequences of this process in terms of $A \beta$ peptide clearance. However, it is important to note that it is not easy to reproduce the "in vitro" effects of $24 \mathrm{~S}-\mathrm{OH}$-chol in in vivo models. Indeed, two different groups recently demonstrated that overexpression of CYP46A1 in mouse brain (resulting in an almost twofold elevation of 24S-OH-chol levels) did not activate the expected LXR target genes such as abcal [54, 62]. It is likely that higher concentrations are needed to activate transcription of the target genes in vivo and that interaction with others oxysterols such as the 27 hydroxycholesterol may account for the regulation of the cellular cholesterol homeostasis.

In summary, our study highlights a new role for the brain pericytes in brain cholesterol homeostasis involving the ABCA1/LXR axis and suggests that naíve $A \beta$ peptides are not direct substrates for ABCA1. Our observations reinforce the idea whereby the use of LXR agonists to modulate brain cholesterol homeostasis may represent a promising therapeutic strategy in $\mathrm{AD}$.

\section{ACKNOWLEDGMENTS}

Valuable technical advice from Stéphane Nion is gratefully acknowledged. This work was funded by grants from the French "Coeur et Artères" foundation (Grant 06T6) and the "Ligue Européenne Contre la Maladie d'Alzheimer" (LECMA) charity (Grant 09752). Julien Saint-Pol and Elodie Vandenhaute received doctoral fellowships from the Ministère de l'Enseignement Supérieur et de la Recherche.

Authors' disclosures available online (http://www.jalz.com/disclosures/view.php?id=1182).

\section{REFERENCES}

[1] Pfrieger FW (2003) Outsourcing in the brain: Do neurons depend on cholesterol delivery by astrocytes? Bioessays $\mathbf{2 5}$, 72-78.

[2] Bjorkhem I, Meaney S (2004) Brain cholesterol: Long secret life behind a barrier. Arterioscler Thromb Vasc Biol 24, 806815

[3] Meaney S, Bodin K, Diczfalusy U, Bjorkhem I (2002) On the rate of translocation in vitro and kinetics in vivo of the major oxysterols in human circulation: Critical importance of the position of the oxygen function. J Lipid Res 43, 2130-2135.

[4] Lutjohann D, Breuer O, Ahlborg G, Nennesmo I, Siden A, Diczfalusy U, Bjorkhem I (1996) Cholesterol homeostasis in human brain: Evidence for an age-dependent flux of 24Shydroxycholesterol from the brain into the circulation. Proc Natl Acad Sci U S A 93, 9799-9804.

[5] Bjorkhem I, Lutjohann D, Diczfalusy U, Stahle L, Ahlborg G, Wahren J (1998) Cholesterol homeostasis in human brain: Turnover of 24S-hydroxycholesterol and evidence for a cerebral origin of most of this oxysterol in the circulation. J Lipid Res 39, 1594-1600.

[6] Kim WS, Weickert CS, Garner B (2008) Role of ATP-binding cassette transporters in brain lipid transport and neurological disease. J Neurochem 104, 1145-1166.

[7] Whitney KD, Watson MA, Collins JL, Benson WG, Stone TM, Numerick MJ, Tippin TK, Wilson JG, Winegar DA, Kliewer SA (2002) Regulation of cholesterol homeostasis by the liver X receptors in the central nervous system. Mol Endocrinol 16, 1378-1385.

[8] Abildayeva K, Jansen PJ, Hirsch-Reinshagen V, Bloks VW, Bakker AH, Ramaekers FC, de Vente J, Groen AK, Wellington CL, Kuipers F, Mulder M (2006) 24(S)-hydroxycholesterol participates in a liver $\mathrm{X}$ receptor-controlled pathway in astrocytes that regulates apolipoprotein E-mediated cholesterol efflux. J Biol Chem 281, 12799-12808.

[9] Karten B, Campenot RB, Vance DE, Vance JE (2006) Expression of ABCG1, but not ABCA1, correlates with cholesterol release by cerebellar astroglia. J Biol Chem 281, 4049-4057. 
[10] Nelissen K, Mulder M, Smets I, Timmermans S, Smeets K, Ameloot M, Hendriks JJ (2012) Liver X receptors regulate cholesterol homeostasis in oligodendrocytes. J Neurosci Res 90, 60-71.

[11] Kim WS, Rahmanto AS, Kamili A, Rye KA, Guillemin GJ, Gelissen IC, Jessup W, Hill AF, Garner B (2007) Role of ABCG1 and ABCA1 in regulation of neuronal cholesterol efflux to apolipoprotein E discs and suppression of amyloidbeta peptide generation. J Biol Chem 282, 2851-2861.

[12] Eckert GP, Vardanian L, Rebeck GW, Burns MP (2007) Regulation of central nervous system cholesterol homeostasis by the liver X receptor agonist TO-901317. Neurosci Lett 423, 47-52.

[13] Fujiyoshi M, Ohtsuki S, Hori S, Tachikawa M, Terasaki T (2007) 24S-hydroxycholesterol induces cholesterol release from choroid plexus epithelial cells in an apical- and apoE isoform-dependent manner concomitantly with the induction of ABCA1 and ABCG1 expression. J Neurochem 100, 968978.

[14] Terwel D, Steffensen KR, Verghese PB, Kummer MP, Gustafsson JA, Holtzman DM, Heneka MT (2011) Critical role of astroglial apolipoprotein $\mathrm{E}$ and liver $\mathrm{X}$ receptor\{alpha\} Expression for microglial A $\{$ beta\} phagocytosis. $J$ Neurosci 31, 7049-7059.

[15] Koldamova RP, Lefterov IM, Staufenbiel M, Wolfe D, Huang S, Glorioso JC, Walter M, Roth MG, Lazo JS (2005) The liver $\mathrm{X}$ receptor ligand T0901317 decreases amyloid beta production in vitro and in a mouse model of Alzheimer's disease. J Biol Chem 280, 4079-4088.

[16] Riddell DR, Zhou H, Comery TA, Kouranova E, Lo CF, Warwick HK, Ring RH, Kirksey Y, Aschmies S, Xu J, Kubek K, Hirst WD, Gonzales C, Chen Y, Murphy E, Leonard S, Vasylyev D, Oganesian A, Martone RL, Pangalos MN, Reinhart PH, Jacobsen JS (2007) The LXR agonist TO901317 selectively lowers hippocampal Abeta42 and improves memory in the Tg2576 mouse model of Alzheimer's disease. Mol Cell Neurosci 34, 621-628.

[17] Burns MP, Vardanian L, Pajoohesh-Ganji A, Wang L, Cooper M, Harris DC, Duff K, Rebeck GW (2006) The effects of ABCA1 on cholesterol efflux and Abeta levels in vitro and in vivo. J Neurochem $\mathbf{9 8}, 792-800$.

[18] Donkin JJ, Stukas S, Hirsch-Reinshagen V, Namjoshi D, Wilkinson A, May S, Chan J, Fan J, Collins J, Wellington CL (2010) ATP-binding cassette transporter A1 mediates the beneficial effects of the liver X receptor agonist GW3965 on object recognition memory and amyloid burden in amyloid precursor protein/presenilin 1 mice. J Biol Chem 285, 34144-34154.

[19] Fitz NF, Cronican A, Pham T, Fogg A, Fauq AH, Chapman R, Lefterov I, Koldamova R (2010) Liver X receptor agonist treatment ameliorates amyloid pathology and memory deficits caused by high-fat diet in APP23 mice. J Neurosci 30, 68626872.

[20] Zelcer N, Khanlou N, Clare R, Jiang Q, Reed-Geaghan EG, Landreth GE, Vinters HV, Tontonoz P (2007) Attenuation of neuroinflammation and Alzheimer's disease pathology by liver x receptors. Proc Natl Acad Sci U S A 104, 10601-10606.

[21] Do TM, Ouellet M, Calon F, Chimini G, Chacun H, Farinotti R, Bourasset F (2011) Direct evidence of abca1-mediated efflux of cholesterol at the mouse blood-brain barrier. Mol Cell Biochem 357, 397-404.

[22] Karasinska JM, Rinninger F, Lutjohann D, Ruddle P, Franciosi S, Kruit JK, Singaraja RR, Hirsch-Reinshagen V, Fan J, Brunham LR, Bissada N, Ramakrishnan R, Wellington CL, Parks JS, Hayden MR (2009) Specific loss of brain ABCA1 increases brain cholesterol uptake and influences neuronal structure and function. J Neurosci 29, 3579-3589.

[23] Schweinzer C, Kober A, Lang I, Etschmaier K, Scholler M, Kresse A, Sattler W, Panzenboeck U (2011) Processing of endogenous A $\beta P P$ in blood-brain barrier endothelial cells is modulated by liver-x receptor agonists and altered cellular cholesterol homeostasis. J Alzheimers Dis 27, 341360 .

[24] Zlokovic BV (2008) The blood-brain barrier in health and chronic neurodegenerative disorders. Neuron 57, 178-201.

[25] Daneman R, Zhou L, Kebede AA, Barres BA (2010) Pericytes are required for blood-brain barrier integrity during embryogenesis. Nature 468, 562-566.

[26] Armulik A, Genove G, Betsholtz C (2011) Pericytes: Developmental, physiological, and pathological perspectives, problems, and promises. Dev Cell 21, 193-215.

[27] Gosselet F, Candela P, Sevin E, Berezowski V, Cecchelli R, Fenart L (2009) Transcriptional profiles of receptors and transporters involved in brain cholesterol homeostasis at the blood-brain barrier: Use of an in vitro model. Brain Res $\mathbf{1 2 4 9}$, 34-42.

[28] Panzenboeck U, Balazs Z, Sovic A, Hrzenjak A, Levak-Frank S, Wintersperger A, Malle E, Sattler W (2002) ABCA1 and scavenger receptor class $\mathrm{B}$, type I, are modulators of reverse sterol transport at an in vitro blood-brain barrier constituted of porcine brain capillary endothelial cells. J Biol Chem 277, 42781-42789.

[29] Panzenboeck U, Kratzer I, Sovic A, Wintersperger A, Bernhart E, Hammer A, Malle E, Sattler W (2006) Regulatory effects of synthetic liver $\mathrm{X}$ receptor- and peroxisomeproliferator activated receptor agonists on sterol transport pathways in polarized cerebrovascular endothelial cells. Int J Biochem Cell Biol 38, 1314-1329.

[30] Akanuma S, Hori S, Ohtsuki S, Fujiyoshi M, Terasaki T (2008) Expression of nuclear receptor mRNA and liver $\mathrm{X}$ receptor-mediated regulation of $\mathrm{ABC}$ transporter $\mathrm{A} 1$ at rat blood-brain barrier. Neurochem Int 52, 669-674.

[31] Candela P, Gosselet F, Saint-Pol J, Sevin E, Boucau MC, Boulanger E, Cecchelli R, Fenart L (2010) Apicalto-basolateral transport of amyloid-beta peptides through blood-brain barrier cells is mediated by the receptor for advanced glycation end-products and is restricted by $\mathrm{P}$ glycoprotein. J Alzheimers Dis 22, 849-859.

[32] Vandenhaute E, Dehouck L, Boucau MC, Sevin E, Uzbekov R, Tardivel M, Gosselet F, Fenart L, Cecchelli R, Dehouck MP (2011) Modelling the neurovascular unit and the blood-brain barrier with the unique function of pericytes. Curr Neurovasc $\operatorname{Res}$ 8, 258-269.

[33] Meresse S, Dehouck MP, Delorme P, Bensaid M, Tauber JP, Delbart C, Fruchart JC, Cecchelli R (1989) Bovine brain endothelial cells express tight junctions and monoamine oxidase activity in long-term culture. J Neurochem 53, 13631371.

[34] Boucher K, Siegel CS, Sharma P, Hauschka PV, Solomon KR (2006) HMG-CoA reductase inhibitors induce apoptosis in pericytes. Microvasc Res 71, 91-102.

[35] Favari E, Lee M, Calabresi L, Franceschini G, Zimetti F, Bernini F, Kovanen PT (2004) Depletion of pre-beta-high density lipoprotein by human chymase impairs ATP-binding cassette transporter A1- but not scavenger receptor class B type I-mediated lipid efflux to high density lipoprotein. J Biol Chem 279, 9930-9936.

[36] Stefulj J, Panzenboeck U, Becker T, Hirschmugl B, Schweinzer C, Lang I, Marsche G, Sadjak A, Lang U, Desoye G, Wadsack C (2009) Human endothelial cells of the placen- 
tal barrier efficiently deliver cholesterol to the fetal circulation via $\mathrm{ABCA1}$ and $\mathrm{ABCG1}$. Circ Res 104, 600-608.

[37] O'Connell BJ, Denis M, Genest J (2004) Cellular physiology of cholesterol efflux in vascular endothelial cells. Circulation 110, 2881-2888.

[38] Akanuma S, Ohtsuki S, Doi Y, Tachikawa M, Ito S, Hori S, Asashima T, Hashimoto T, Yamada K, Ueda K, Iwatsubo T, Terasaki T (2008) ATP-binding cassette transporter A1 (ABCA1) deficiency does not attenuate the brain-to-blood efflux transport of human amyloid-beta peptide (1-40) at the blood-brain barrier. Neurochem Int 52, 956-961.

[39] Lefterov I, Fitz NF, Cronican AA, Fogg A, Lefterov P, Kodali R, Wetzel R, Koldamova R (2010) Apolipoprotein A-I deficiency increases cerebral amyloid angiopathy and cognitive deficits in APP/PS1DeltaE9 mice. J Biol Chem 285, 3694536957.

[40] Wilhelmus MM, Otte-Holler I, van Triel JJ, Veerhuis R, MaatSchieman ML, Bu G, de Waal RM, Verbeek MM (2007) Lipoprotein receptor-related protein-1 mediates amyloidbeta-mediated cell death of cerebrovascular cells. Am J Pathol 171, 1989-1999.

[41] Verbeek MM, de Waal RM, Schipper JJ, Van Nostrand WE (1997) Rapid degeneration of cultured human brain pericytes by amyloid beta protein. J Neurochem $\mathbf{6 8}, 1135-1141$.

[42] Berezowski V, Landry C, Dehouck MP, Cecchelli R, Fenart L (2004) Contribution of glial cells and pericytes to the mRNA profiles of P-glycoprotein and multidrug resistanceassociated proteins in an in vitro model of the blood-brain barrier. Brain Res 1018, 1-9.

[43] Bjorkhem I (2006) Crossing the barrier: Oxysterols as cholesterol transporters and metabolic modulators in the brain. J Intern Med 260, 493-508.

[44] Nieland TJ, Chroni A, Fitzgerald ML, Maliga Z, Zannis VI, Kirchhausen T, Krieger M (2004) Cross-inhibition of SRBI- and ABCA1-mediated cholesterol transport by the small molecules BLT-4 and glyburide. J Lipid Res 45, 1256-1265.

[45] Wu CA, Tsujita M, Hayashi M, Yokoyama S (2004) Probuco inactivates ABCA1 in the plasma membrane with respect to its mediation of apolipoprotein binding and high density lipoprotein assembly and to its proteolytic degradation. J Biol Chem 279, 30168-30174.

[46] Wojcicka G, Jamroz-Wisniewska A, Horoszewicz K, Beltowski J (2007) Liver X receptors (LXRs). Part I: Structure, function, regulation of activity, and role in lipid metabolism. Postepy Hig Med Dosw (Online) 61, 736-759.

[47] Ikonen E (2008) Cellular cholesterol trafficking and compartmentalization. Nat Rev Mol Cell Biol 9, 125-138.

[48] Strittmatter WJ, Saunders AM, Schmechel D, Pericak-Vance M, Enghild J, Salvesen GS, Roses AD (1993) Apolipoprotein E: High-avidity binding to beta-amyloid and increased frequency of type 4 allele in late-onset familial Alzheimer disease. Proc Natl Acad Sci U S A 90, 1977-1981.

[49] Michikawa M, Fan QW, Isobe I, Yanagisawa K (2000) Apolipoprotein E exhibits isoform-specific promotion of lipid efflux from astrocytes and neurons in culture. $J$ Neurochem 74, 1008-1016.

[50] Krimbou L, Denis M, Haidar B, Carrier M, Marcil M, Genest $\mathrm{J} J \mathrm{r}$ (2004) Molecular interactions between apoE and ABCA1: Impact on apoE lipidation. J Lipid Res 45, 839-848.
[51] Castellano JM, Kim J, Stewart FR, Jiang H, DeMattos RB, Patterson BW, Fagan AM, Morris JC, Mawuenyega KG, Cruchaga C, Goate AM, Bales KR, Paul SM, Bateman RJ, Holtzman DM (2011) Human apoE isoforms differentially regulate brain amyloid-beta peptide clearance. Sci Transl Med 3, 57-67.

[52] Deane R, Sagare A, Hamm K, Parisi M, Lane S, Finn MB, Holtzman DM, Zlokovic BV (2008) apoE isoform-specific disruption of amyloid beta peptide clearance from mouse brain. J Clin Invest 118, 4002-4013.

[53] Vanmierlo T, Rutten K, Dederen J, Bloks VW, van Vark-van der Zee LC, Kuipers F, Kiliaan A, Blokland A, Sijbrands EJ, Steinbusch H, Prickaerts J, Lutjohann D, Mulder M (2011) Liver $\mathrm{X}$ receptor activation restores memory in aged $\mathrm{AD}$ mice without reducing amyloid. Neurobiol Aging 32, 1262-1272.

[54] Hudry E, Van Dam D, Kulik W, De Deyn PP, Stet FS, Ahouansou O, Benraiss A, Delacourte A, Bougneres P, Aubourg P, Cartier N (2010) Adeno-associated virus gene therapy with cholesterol 24-hydroxylase reduces the amyloid pathology before or after the onset of amyloid plaques in mouse models of Alzheimer's disease. Mol Ther 18, 44-53.

[55] Wahrle SE, Jiang H, Parsadanian M, Kim J, Li A, Knoten A, Jain S, Hirsch-Reinshagen V, Wellington CL, Bales KR, Paul SM, Holtzman DM (2008) Overexpression of ABCA1 reduces amyloid deposition in the PDAPP mouse model of Alzheimer disease. J Clin Invest 118, 671-682.

[56] Wahrle SE, Jiang H, Parsadanian M, Hartman RE, Bales KR, Paul SM, Holtzman DM (2005) Deletion of Abcal increases Abeta deposition in the PDAPP transgenic mouse model of Alzheimer disease. J Biol Chem 280, 43236-43242.

[57] Koldamova R, Staufenbiel M, Lefterov I (2005) Lack of ABCA1 considerably decreases brain ApoE level and increases amyloid deposition in APP23 mice. J Biol Chem 280, 43224-43235.

[58] Hirsch-Reinshagen V, Maia LF, Burgess BL, Blain JF, Naus KE, McIsaac SA, Parkinson PF, Chan JY, Tansley GH, Hayden MR, Poirier J, Van Nostrand W, Wellington CL (2005) The absence of ABCA1 decreases soluble ApoE levels but does not diminish amyloid deposition in two murine models of Alzheimer disease. J Biol Chem 280, 43243-43256.

[59] Koldamova R, Fitz NF, Lefterov I (2010) The role of ATPbinding cassette transporter A1 in Alzheimer's disease and neurodegeneration. Biochim Biophys Acta 1801, 824-830.

[60] Bendayan R, Ronaldson PT, Gingras D, Bendayan M (2006) In situ localization of P-glycoprotein (ABCB1) in human and rat brain. J Histochem Cytochem 54, 1159-1167.

[61] Martins IJ, Berger T, Sharman MJ, Verdile G, Fuller SJ, Martins RN (2009) Cholesterol metabolism and transport in the pathogenesis of Alzheimer's disease. J Neurochem 111, 12751308.

[62] Shafaati M, Olin M, Bavner A, Pettersson H, Rozell B, Meaney S, Parini P, Bjorkhem I (2011) Enhanced production of 24S-hydroxycholesterol is not sufficient to drive liver $\mathrm{X}$ receptor target genes in vivo. J Intern Med 270, 377-387. 